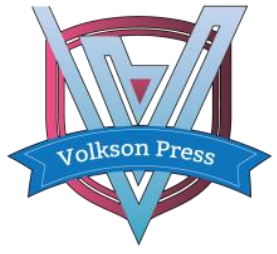

\title{
AN EMPIRICAL RESEARCH ON BIT'S INFLUENCE ON CHINA'S INWARD FDI
}

\author{
Ravi Ranjan Kushwaha1,2*, Chen Yu' ${ }^{1,2}$ \\ 1 School of Economics and Commerce, South China University of Technology, Guangzhou, China \\ ${ }^{2}$ The National Social Science Fund of China (16BJL094); Soft Science Research Program of Guangdong Province (2016A070705007) \\ *Corresponding Author: raviranjan@163.com
}

This is an open access article distributed under the Creative Commons Attribution License, which permits unrestricted use, distribution, and reproduction in any medium, provided the original work is properly cited.

\section{ARTICLE DETAILS}

\section{Article History:}

Received 12 March 2018 Accepted 12 April 2018

Available online 15 May 2018

\begin{abstract}
Countries all around the world with motive to attract, promote and protect Foreign Investments, have signed thousands of Bilateral Investment Treaties (BIT) in last three decades. But the effect of Bilateral Investment Treaties on Foreign Direct Investment (FDI) is still debatable. The concept of analyzing the heterogeneity of BITs have started only in recent years. OECD nations are the source of most of the World's Foreign Direct Investment and China has the second highest number of signed Bilateral Investment Treaties. It would be interesting to analyze the effect of heterogeneous BIT on China's Inward Foreign Direct Investment. We empirically study the effect of heterogeneous BIT on Foreign Direct Investment by analyzing the data from the year 2000 to 2016. The empirical result suggests no significant correlation between heterogeneous BIT and China's Inward Foreign Direct Investment. However, complying with the gravity model, empirical results show positive correlation with economy size and openness, negatively with distance. It also shows positive correlation with Institutional Quality Indicator variables like Political Stability, Government Effectiveness.
\end{abstract}

\section{KEYWORDS}

Bilateral Investment Treaty, Foreign Direct Investment, China.

\section{INTRODUCTION}

Foreign Direct investment accounts for more than 40 percent of external development finance to developing and transition economies. As per the data from World Bank, the net outflow of Foreign Direct Investment of the world has increased from 220 billion US dollars in 1991 to 1.9 trillion dollars in 2016. OECD countries contribute about $75 \%$ of the net outflow of Foreign Direct Investment which amounted to 1.42 trillion US dollars in the 2016. China has been a leading country in receiving the global Foreign Direct Investment. Its annual realized inflow of Foreign Direct Investment has grown from 1.9 billion US dollars in 1985 to 131 billion US dollars in the year 2017 [1].

Bilateral Investment Treaties are the most widely used international agreements both for protecting foreign investors and providing such investments non- discriminatory treatment. As per the latest data from United Nations Conference on Trade and Development (UNTCAD), there are 2948 BITs signed between different nations, regions and territories [1]. Of them 2364 of BITs are in force, the rest not in force/replaced by new BITs or eliminated. However, such important role of BIT and key provisions of these treaties are controversial because different researchers have come to different conclusions which points to the heterogeneity of BITs. According to the data from UNCTAD, China has signed $145 \mathrm{BITs}$, of which 109 remain in force and the rest either are not in force(implemented)/ terminated or replaced by new BIT's [1]. With such many signed and implemented BITs for one country, the actual impact of BITs on FDI into a developing country as China is of interest.

\section{LITERATURE REVIEW}

There is general belief that BITs are concluded to attract Foreign Direct Investment. However, different studies in the past have shown different results making their effectiveness a question of debate. As state in a study, many variables influence investors' investment decisions, including various economic and political factors [2]. This complexity makes it difficult to distinguish the effect of a BIT from other factors affecting investment. We summarize past studies in three categories, positive or negative effect of BITs on FDI and heterogeneity of BITs.

As per the study from a group researcher, large number of BITs leads to higher FDI inflows to developing nations [3]. They also show the evidence of BITs as a substitute for a favorable local business environment. A researcher, applying gravity model with instrument approach, has shown that BITs do help to push up FDI inflows to developing countries and BITs even substitute for weak domestic institutions. In their study, regard BITs as a credible commitment device because of access to international arbitration for the investors and hence attracting more FDI [4,5]. Some group researchers also apply a competitive model to clarify the reasons for the expectation of higher FDI [6]. According to them, in order to gain reputational advantage and to have upper hand in possible competition with other host countries which also struggle to attract the similar types of FDI, it is normal for a country to look forward to signing more BITs.

A researcher in their study using econometrics found a non-significant negative coefficient for total BITS signed by a country and a positive but very weak correlation beginning five years after a BIT was signed [7]. They concluded that there was no evidence to support that BITs attracts Foreign Direct Investments. In 2005, study conducted by Jennifer Tobin and Susan Rose-Ackerman using data from 1984 to 2000 on inbound FDI to 176 low and middle-income countries found little effect on FDI. The study found that BITs had a negative effect on aggregate FDI inflows at high levels of political risk and began to have a small positive effect at high levels of stability. They concluded that BITs merely reflect whether countries already have strong domestic institutions and have no independent effect on attracting investment. In his research, using Meta methodology shows that the marginal effect of a single BIT diminishes as the number of BITs goes up, causing low or statistically insignificant effect sizes [8].

Many researches have been conducted on BITs correlation and effect on Foreign Direct Investments. But most of the researches have treated all the BITs as equal or homogenous. Others researcher in their research show that BITs of some countries with the United states are sticker than with 
other OECD countries showing that all BITs are not same [9]. In his study, a researcher explains that generalization of the BITs in cross country analysis could not capture its heterogeneity resulting no or little effect on FDI [10]. A researcher in his work has mentioned improving the different articles of BIT can help to attract more Foreign Direct Investment [11]. In his study finds that the dispute settlement clause in the recent BITs help to promote more FDI [12]. Above researches show that BITs heterogeneous nature should be considered.

\section{DATA}

We construct a panel data from the year 2000 to 2016 for the FDI inflows from the OECD countries to China. We get the data of FDI inflows to China from the National Bureau of Statistics database of China which is the value of actual utilized FDI by China in a particular year. We get annual data such as Gross Domestic Product (GDP), exchange rate from OECD and World bank database. Time invariant Variable such as Distance which is the distance between the capital of outward FDI flowing country and Beijing is calculated from the website chemical ecology.net. Annual data for Openness is collected from World Bank database. Similarly, country's institutional data such as Political Stability and Absence of Violence, Regulatory Quality, Control of Corruption, Voice and Accountability, Government Effectiveness and Rule of Law are from World Bank database under the topic World Governance Indicators.

\section{EMPIRICAL STRATEGIES}

\subsection{BIT Index}

We construct BIT index which has two parts. First coding each article and second is applying Principal Component analysis to obtain the final index. For coding the articles, we take in consideration the suggested articles from a study which includes Definition of Investment, Admission vs. Establishment, National Treatment, Most Favored Nations, Fair and Equitable Treatment, Direct and Indirect Expropriation, Free Transfer of
Investment-related Funds, Non-Economic Standards, Investor-State Dispute Settlement, Umbrella Clause and Temporal Scope of Application [8]. We have based our analysis on collected 42 BITs which has been signed between China and 33 OECD countries. Out of 35 OECD nations, United Sates of America and Ireland don't have BITs with China. There are few countries where the BITs were replaced by a new one. The BITs which were replaced by a new BIT during the duration of our data set (i.e 20002016) have been treated as new BIT and coded their articles separately. The countries nations and territories that have replaced new BIT during the period are China- Belguim-Luxembourg BIT in 2005 entering in force in 2009; China- Czech Republic BIT in 2005 entering in force in 2006; China-Finland BIT in 2004 entering in force in 2006; China-France BIT in 2007 entering into force in 2010; China-Germany BIT in 2003 entering in force in 2005; China-Korea BIT in 2007 entering in force the same year; China-Netherland BIT in 2001 entering in force from 2004; China-Portugal BIT in 2005 entering in force in 2008; China-Spain BIT in 2005 entering in force in 2008; China-Switzerland BIT in 2009 entering in force a year later and China-Turkey BIT in 2015 but not in force yet. We haven't coded the articles of the new BIT with Turkey as its not in force yet.

We follow the BITSEL Index proposed by two researchers and quote eleven main articles of a BIT accordingly [8]. The code for each article is comprised of two values of 1 and 2 . Value 1 shows more favorable condition for investors than 1 . The Table 1 below presents summary statistics of articles in the BIT sample of 42 BITs. In the table below shows that article 6 (Direct and Indirect Expropriation) is present in all the BITs considered in this study showing variation at all. So, this article isn't used for BIT construction.

After we finish coding of articles, the methodology of Principal Component Analysis (PCA) has been applied. The principle for using this method is that we could find out the different components, each of which contains the underlying information about how it can explain the change in variables of articles (variance). In another way we could say about the composition of different variables (weights) in each component.

Table 1: Summary statistics of Articles in the BIT sample

\begin{tabular}{r|rrrrr} 
Variable & Obs & Mean & Std. Dev. & Min & Max \\
\hline article1 & 42 & 1.97619 & .1543033 & 1 & 2 \\
article2 & 42 & 1.047619 & .2155403 & 1 & 2 \\
article3 & 42 & 1.333333 & .4771187 & 1 & 2 \\
article4 & 42 & 1.714286 & .45723 & 1 & 2 \\
article5 & 42 & 1.880952 & .3277701 & 1 & 2 \\
\hline article6 & 42 & 2 & 0 & 2 & 2 \\
article7 & 42 & 1.238095 & .4310805 & 1 & 2 \\
article8 & 42 & 1.928571 & .2606612 & 1 & 2 \\
article9 & 42 & 1.285714 & .45723 & 1 & 2 \\
article10 & 42 & 1.5 & .5060608 & 1 & 2 \\
\hline article11 & 42 & 1.642857 & .4849656 & 1 & 2
\end{tabular}

Based on the eigenvalue value (which is bigger than 1 with 4 components), we decided to select 4 components for our data analysis. The variations of our 10 articles in the sample (except Article 6 of Direct and Indirect Expropriation) are explained more than $50 \%$ by our 4 components. With the exact values of these 4 components (ranging from 1 to 1 ) provided by PCA representing 4 types of weight, we take the simple average to have our one value of weight (initial BIT index). Finally, we rescale our values to get the final BIT index ranging from slightly $6.88025 \mathrm{E}-07$ to 1 . The higher values of BIT index indicate more favorable condition for foreign investment or investors.

\section{Empirical Formula}

Then the gravity model is applied to consider the impact of heterogeneous BIT on FDI inflows to China. The main empirical specification for random effect model for panel data is as below:

$\operatorname{LogFDI}_{\text {icnt }}=a$ aBTindex $_{i c n t}+\beta_{1} \operatorname{LogGDP}{ }_{i t}+{ }_{\beta 2} \operatorname{LogGDP}_{c n}+\beta_{3} \operatorname{LogDisti}_{c n}+\beta_{4}$ Inflat ion $_{i t} /$ Inflation $_{\text {cnt }}+\beta_{5} V A_{i t} / V A_{c n t}+\beta_{6}$ Open $_{i t} /$ Open $_{\text {cnt }}+\beta_{7} G_{\text {Git }} / G_{\text {cnt }}+\beta_{8}$ $\operatorname{CCOR}_{i t} / \operatorname{CCOR}_{c n t}+\beta_{9} \operatorname{CCOR}_{i t} / \operatorname{CCOR}_{c n t}+\beta_{10} R Q_{i t} / R_{c n t}+\beta_{11} P S V_{i t} / P S V_{c n t}+\beta_{12}$ $R_{O L} L_{i t} / R_{O L}$ cnt $+\varphi t+\varepsilon i c n t$
Where i denotes country $\mathrm{i}$, $\mathrm{cn}$ denotes China, $\mathrm{t}$ is year $\mathrm{t}$.

- $\boldsymbol{L o g F D I}_{\boldsymbol{c} \text { t }}$ is the FDI inflow from country i to China in year t;

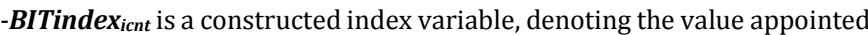
to a BIT between country i and China at year t;

- $\boldsymbol{L o g} \boldsymbol{G D P}$ it denotes the log gross domestic product of country i in year t;

- $\log \boldsymbol{G D P} \boldsymbol{P}_{\boldsymbol{c} \text { t }}$ denotes the log gross domestic product of China in year t;

- LogDist $_{\text {icn }}$ is the log distance between capital of country i and China's capital Beijing;

$-\boldsymbol{\varphi t}$ denotes time dummies

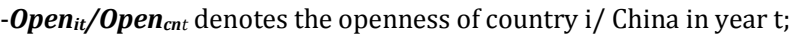

-Inflation $_{\text {it }}$ /Inflation $_{\text {cnt }}$ is the inflation rate of county i/ China in year t;

- $\boldsymbol{V} \boldsymbol{A}_{\boldsymbol{i t}} / \boldsymbol{V} \boldsymbol{A}_{\boldsymbol{c} \text { cht }}$ is the index of Voice and Accountability of country i/ China in yeart; 
- $\boldsymbol{G} \boldsymbol{E}_{\boldsymbol{i t}} / \boldsymbol{G} \boldsymbol{E}_{\boldsymbol{c n t}}$ is the index of Government Effectiveness of country i/ China in year t;

- $\operatorname{CCOR}_{i t} / \boldsymbol{C C O R}_{\boldsymbol{c n t}}$ is the index of Control of Corruption of country i/ China in year t;

$\boldsymbol{R} \boldsymbol{Q}_{i t} / \boldsymbol{R} \boldsymbol{Q}_{\boldsymbol{c n t}}$ is the index of Regulatory Quality of country i/ China in year t;

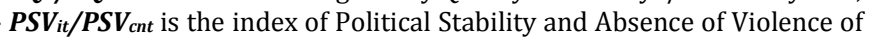
country i/ China in year t;

$\boldsymbol{R O L}_{i t} / \boldsymbol{R O L}_{\text {cnt }}$ is the index of Rule of Law of country i/ China in year t. The coefficient of interest in the above equation is $a$, which measures the effect of China's BIT signing on FDI inflows. If BIT does help China attract more FDI, this coefficient will be positive

\section{RESULT}

After getting the final value of BIT index through Principal Component Analysis, we construct our data set to analyze the effect of heterogeneous BIT effect on FDI inflows. We have used BIT index (BITindex ${ }_{i c n t}$ ), Gross Domestic Product of China, Gross Domestic Product of country i, and log of distances between the China and country i which are the basic variables and have been used by most of the researchers. At first we use Random Effect regression and get the results. We again run Fixed Effect regression and obtain the results. The obtained results are shown in Table 2 below. Column (1) and Column (3) show the result of Random Effect and Fixed effect respectively. We use Breusch-Pagan Lagrange multiplier test to help confirm Random effect technique is appropriate.

The coefficient of LogGDP of country $\mathrm{i}$ (LogGDP $\mathrm{Lit}_{\mathrm{it}}$ is positive however the LogGDP of China ( $\operatorname{LogGDP}_{\mathrm{cn}}$ ) does not have any significant effect. Increase in the GDP of the OECD countries increases the flow of FDI in China. With an increase of $1 \%$ of country i's GDP, the FDI inflow in China increases by $1.5 \%$ to $2.8 \%$. The coefficient of LogDisticn is negative and significant. With an increase in distance between China and partner country by $1 \%$, the FD flow decreases by $0.8 \%$ to $1.18 \%$. This is consistent with the gravity model. The FDI decreases with the increase in distance which reflect increase in transportation cost and thus less attractive to investors. However, to our biggest surprise the coefficient of BIT index is positive but insignificant. When we repeat the regression in addition with other variables like Openness Inflation and Institutional variables, there is negative coefficient and is still insignificant. This result is opposite to our expectation however is in line with the finding of other authors in past $[7,13,14]$. While the above result and different authors suggest that BIT do not serve to attract additional FDI, it is possible that this is due to its being obscured by other changes that are occurring between two signatories over time such as lowering trade barriers, increased knowledge of conducting business in the host country, following customers abroad etc.

In the Table 4 column (3) and (4) shows the regression result when we add other variables like ratio of the inflation of FDI providing country and China, ratio of Openness of country i and China. Also, institutional quality indicator variables such as Political Stability and Absence of Violence $\left(\mathrm{PSV}_{\mathrm{it}} / \mathrm{PSV}_{\mathrm{cn}}\right)$, Voice and Accountability $\left(\mathrm{VA}_{\mathrm{it}} / \mathrm{VA}_{\mathrm{cnt}}\right)$, Control of Corruption ( $\mathrm{CCOR}_{\mathrm{it}} / \mathrm{CCOR}_{\mathrm{cnt}}$ ), Regulatory Quality ( $\left(\mathrm{RQ}_{\mathrm{it}} / \mathrm{RQ}_{\mathrm{cnt}}\right)$, Government Effectiveness $\left(\mathrm{GE}_{\mathrm{it}} / \mathrm{GE}_{\mathrm{cnt}}\right)$, Rule of law $\left(\mathrm{ROL}_{\mathrm{it}} / \mathrm{ROL}_{\mathrm{cn}}\right)$ are added and their effect on FDI is checked. We find that ratio of Openness has positive and significant coefficient which means it increases Foreign Direct Investment. Similarly, the ratio of institutional quality variables Political Stability and Absence of Violence, Government Effectiveness has positive effect on FDI $[15,16]$. While ratio of Regulatory Quality, Rule of Law and Voice and Accountability have negative coefficient.

Table 2: Baseline result for FDI

\begin{tabular}{|c|c|c|c|c|}
\hline & \multicolumn{4}{|l|}{$\log F D I_{i c n t}$} \\
\hline & (1) & (2) & (3) & $(4)$ \\
\hline \multirow[t]{2}{*}{ BIT index ${ }_{\text {icnt }}$} & 0.0064 & -0.0175 & -0.1817 & -0.1744 \\
\hline & $(0.03)$ & $(-0.09)$ & $(-1.18)$ & $(-0.85)$ \\
\hline \multirow[t]{2}{*}{${\log G D P_{i t}}$} & $1.5606^{* * *}$ & $2.8871^{* * *}$ & $1.5287^{* * *}$ & $2.544^{* * *}$ \\
\hline & (10.31) & $(5.84)$ & (17.21) & $(4.47)$ \\
\hline \multirow[t]{2}{*}{$\log G D P_{c n t}$} & -0.0292 & $-0.2978^{* *}$ & -0.2957 & -0.3847 \\
\hline & $(-0.32)$ & $(-2.21)$ & $(-1.25)$ & $(-1.34)$ \\
\hline \multirow{2}{*}{ LogDist $_{\text {icn }}$} & $-0.8094601^{*}$ & & $-1.1835^{* * *}$ & \\
\hline & $(-1.66)$ & & $(-4.48)$ & \\
\hline \multirow[t]{2}{*}{ Inflation $_{i} /$ Inflation $_{c n}$} & & & 0.14806 & 0.2214 \\
\hline & & & $(0.67)$ & $(0.96)$ \\
\hline \multirow[t]{2}{*}{ Open $_{i t} /$ Open $_{\text {cnt }}$} & & & $0.1252^{* * *}$ & 0.0412 \\
\hline & & & $(3.46)$ & $(0.95)$ \\
\hline \multirow[t]{2}{*}{$V A_{i t} / V A_{c n t}$} & & & $-0.9306^{* * *}$ & -0.3461 \\
\hline & & & $(-4.83)$ & $(-1.52)$ \\
\hline \multirow[t]{2}{*}{$P S V_{i t} / P S V_{c n t}$} & & & $0.0634^{* * *}$ & $0.0749^{* * *}$ \\
\hline & & & $(3.02)$ & (3.43) \\
\hline \multirow[t]{2}{*}{$G E_{i t} / G E_{c n t}$} & & & $0.0006^{* * *}$ & $0.0005^{* *}$ \\
\hline & & & $(2.93)$ & $(2.47)$ \\
\hline \multirow[t]{2}{*}{$R Q_{i t} / R Q_{c n t}$} & & & $-0.379 * * *$ & -0.0075 \\
\hline & & & $(-3.60)$ & $(-0.67)$ \\
\hline \multirow[t]{2}{*}{$R O L_{i t} / R O L_{c n t}$} & & & $-0.0431^{* *}$ & -0.0174 \\
\hline & & & $(-1.82)$ & $(-0.74)$ \\
\hline \multirow[t]{2}{*}{$\mathrm{CCOR}_{i t} / \mathrm{CCOR}_{\text {cnt }}$} & & & -0.0013 & -0.0037 \\
\hline & & & $(-0.08)$ & $(-0.22)$ \\
\hline Rsquared & & 0.0829 & & 0.1198 \\
\hline Type & $\mathrm{RE}$ & $\mathrm{FE}$ & $\mathrm{RE}$ & $\mathrm{FE}$ \\
\hline No. of observation & 561 & 561 & 569 & 569 \\
\hline
\end{tabular}

(Dependable variable is $\log _{10}$ of FDI from country $i$ to China.)

${ }_{* * *} / * * / * *$ shows significant level of $\mathrm{t}$-statistics at $1 \% / 5 \% / 10 \%$ respectively

\section{CONCLUSION}

From the above result we find that there is strong correlation between FDI flow and the GDP of partner country. A country with large GDP will have more flow of investment into China and with increase in the GDP of the partner country the flow of FDI into China will increase further. Also, the nearer partner country is likely to invest more in China than a partner country far away from China. Analyzing the data from 2000-2016 between OECD countries and China using random effect technique for Panel data, significant effect of heterogeneous BIT on Foreign Direct Investment could not be ascertained fully as the results were insignificant. So, it's important to examine whether BITs are delivering their expected benefits before signing more and more BITs. Since our analysis is based on only the OECD countries, further study is suggested including the south-south BITs effect to check if they produce any correlation.

\section{REFERENCES}

[1] World Investment Report 2015,2017, UNTCAD

[2] Buthe, T., Milner, H.V. 2008. The Politics of Foreign Direct Investment into Developing Countries: Increasing FDI through International Trade 
Agreements? American Journal of Political Science, 52 (4), 741-762.

[3] Neumayer, E., Spess, L. 2005. Do Bilateral Investment Treaties Increase Foreign Direct Investment to Developing Countries? World Development 33 (10), 1567-1585

[4] Busse, M., Königer, J., Nunnenkamp, P. 2010. FDI Promotion through Bilateral Investment Treaties: More Than a Bit?. Review of World Economics, 146 (1), 147-177.

[5] Allee, T., Peinhardt, C. 2011. Contingent Credibility: The Impact of Investment Treaty Violations on Foreign Direct Investment. International Organization, 65, 401-432.

[6] Elkins, Z., Guzman, A.T., Simmons, B.A. 2006. Competing for Capital: The Diffusion of Bilateral Investment Treaties, 1960-2000. International Organization, 60 (4), 811-846.

[7] Hallward-Driemeier, M. 2003. Do Bilateral Investment Treaties Attract Foreign Direct Investment? Only a Bit and They Could Bite. Only a Bit and They Could Bite (June 2003). World Bank Policy Research Working Paper, 3121.

[8] Bellak, C. 2013. How Bilateral Investment Treaties Impact on Foreign Direct Investment: A Meta-analysis of Public Policy. Version for 2013 MAER Network Colloquium.

[9] Salacuse, J.W., Sullivan, N.P. 2005. Do BITs Really Work? An Evaluation of Bilateral Investment Treaties and their Grand Bargain. Harvard International Law Journal, 46 (1), 67-130.
[10] Swenson, D.L. 2005. Why do Developing Countries Sign BITs? U.C. Davis Journal of International Law and Policy, 12 (1), 131-155.

[11] Nguyen, T.V.H., Cao, T.H.V., Lu, T.T.T. 2014. The Impact of Heterogeneous Bilateral Investment Treaties (BIT) on Foreign Direct Investment (FDI) inflows to Vietnam. SECO / WTI Academic Cooperation Project Working Paper Series, 03, 41 Pp.

[12] Kerner. 2009. Why should I believe you? The Costs and Consequences of Bilateral Investment Treaties. International Studies Quarterly, 53 (1), 73-102.

[13] Tobin, J., Rose-Ackerman, S. 2005. Foreign Direct Investment and the Business Environment in Developing Countries: The Impact of Bilateral Investment Treaties 13-16 (Yale Law School Ctr. for Law, Econ. \& Pub. Pol'y Research, Working Paper No. 293.

[14] Chaisse, J., Bellak, C. 2011. Do Bilateral Investment Treaties Promote Foreign Direct Investment? Preliminary Reflections on a New Methodology. Transnational Corporations Review, 3 (4), 3-11.

[15] Ministry of Commerce, People's Republic of China. (www.mofcom.gov.cn)

[16] Wälde, K. 2005. Endogenous Growth Cycles. International Economic Review, 46, 867-894. 